Journal of Finance Research

\title{
Research on the Promotion Mechanism of "Innovation-Capital" Inter- active Co-operation——Taking WuXi AppTec As an Example
}

\section{Yan Wang ${ }^{1}$ Jiaan Liu $^{2 *}$ Ziyu Yan ${ }^{3}$}

1. School of Accounting, Guangdong University of Foreign Studies, Guangzhou, Guangdong, 510006, China

2. School of Accounting, Guangdong University of Finance \& Economics, Guangzhou, Guangdong, 510320, China

3. South China Normal University Affiliated High School, Guangzhou, Guangdong, 510613, China

\begin{tabular}{l}
\hline ARTICLE INFO \\
\hline Article history \\
Received: 25 March 2020 \\
Revised: 7 April 2020 \\
Accepted: 9 October 2020 \\
Published Online: 16 October 2020 \\
\hline
\end{tabular}

Keywords:

Technological innovation

Capital operation

WuXi AppTec

\begin{abstract}
Based on the case of WuXi AppTec, this paper explores the mechanism of private innovative enterprises to realize enterprise value growth through innovation-capital interaction in the framework of life growth cycle. This paper constructs a mechanism of interactive coexistence of innovation and capital, which has certain enlightenment and reference significance for innovative enterprises to realize technology catch-up and improve their independent innovation ability through capital operation.
\end{abstract}

\section{Introduction}

I n December 2019, an outbreak of Novel coronavirus pneumonia(NCP) caused a serious threat to people's lives and health, and whether there is a vaccine to prevent it has become a matter of great concern. On February 25, 2020, YaoMing Biologics, a subsidiary of WuXi
AppTec, announced that it had reached a co-operation agreement with Vir Biotechnology on the development and production of the vaccine. WuXi AppTec, the parent company of YaoMing Biologics, was founded in 2000, listed in New York Stock Exchange in 2007, delisted in 2014 and listed in A-share market in 2018. It is the only

*Corresponding Author:

Jiaan Liu,

Female, postgraduate student of School of Accounting, Guangdong University of Finance \& Economics;

School of Accounting, Guangdong University of Finance \& Economics, NO.21, Luntou Road, Haizhu District, Guangzhou, Guangdong, 510320, China;

Email: sulliann@outlook.com.

About other authors:

Yan Wang, Female, professor of School of Accounting, Guangdong University of Foreign Studies.

Ziyu Yan, Male, student of South China Normal University Affiliated High School.

Fund Project:

One of the research results of national social science fund granted project (16BGL058), Guangdong Natural Science fund granted project (2018A030313103), Project approved by Guangdong University Student Innovation and Entrepreneurship Education Research Center, and funded by Guangdong University of Finance \& Economics (2018A052459), 2019 University Key Research Projects in Guangdong Province (2019WZDXM015), The Teaching Quality and Teaching Reform Project of University in Guangdong Province in 2019: Teaching Team Project "International Teaching Team for Accounting Major". 
China Concept Stock (CCS) ${ }^{\circledR}$ listed to A-share market in the way of "Approval as soon as Reporting", and successfully listed in Hong Kong in the same year. In just 18 years, how did WuXi AppTec grow into a "Unicorn" in the CRO industry of China? Why can WuXi AppTec become the only one that listed through "Approval as soon as Reporting"? Is its success accidental or inevitable?

From the perspective of the enterprise life cycle, the interactive co-operation of WuXi AppTec's innovation and capital operation has undergone four stages: enterprise initiation and original innovation, $M \& A$ expansion and secondary innovation, privatization and integration innovation, and Cross-listing and continuous innovation. The innovative output formed becomes the endorsement of capital, so based on the innovation output, WuXi AppTec can get financing. In the meantime, these financing fed back as innovation input. Through such a continuous virtuous cycle, WuXi AppTec not only realized the evolution of independent innovation ability from original innovation to continuous innovation, but also achieved the continuous growth of enterprise.

\section{Analysis on the "Innovation-Capital" In- teractive Co-Operation of WuXi AppTec}

\subsection{Enterprise Initiation and Original Innovation}

Before the reform and opening up, medical level in China was poor, the CRO business was also totally blank in 2000. $\mathrm{Li} \mathrm{Ge}^{(2)}$ saw this situation, and he wanted to change. He quit his job in the United States and returned to China to create WuXi AppTec. With his rich experience in the field of medicine, he led WuXi AppTec to establish a set of service systems different from traditional medicine enterprises, starting from the outsourcing of pharmaceutical $R \& D$ services to providing integrated laboratory $R \& D$ and production services. At this time, WuXi AppTec's innovation mainly came from $\mathrm{Li} \mathrm{Ge}$ and his team's intellectual capital, which belonged to the category of original innovation. At the same time, relying on its original innovative strength, WuXi AppTec began to actively seek financing from external investors to alleviate the financing constraints.

(1) China Concept Stock refers to a company registered and listed overseas, but the largest controlling (usually more than $30 \%$ ) or the actual controller is directly or indirectly subordinate to a private enterprise or individual in mainland China.

(2) Li Ge, graduated from Peking University, and obtained a doctor's degree in organic chemistry from Columbia University. He is the founder of Wuxi AppTec, the largest outsourcing service company for new drug research and development in China, and has served as the chairman and CEO until now.
Table 1. Financing sources of Wuxi AppTec in the initial stage

\begin{tabular}{|c|c|c|c|}
\hline Date & $\begin{array}{c}\text { Financing } \\
\text { Amount }\end{array}$ & $\begin{array}{c}\text { Financing } \\
\text { Round }\end{array}$ & Investor \\
\hline $07 / 01 / 2005$ & $\$ 2.21$ million & Series A & $\begin{array}{c}\text { Tiandi Capital, UOB } \\
\text { Venture Management, } \\
\text { Fidelity International }\end{array}$ \\
\hline $10 / 01 / 2006$ & $\$ 19.2$ million & Series B & $\begin{array}{c}\text { Eight Roads, Tiandi } \\
\text { Capital, UOB Venture } \\
\text { Management }\end{array}$ \\
\hline $02 / 01 / 2007$ & $\$ 54.5$ million & Series C & $\begin{array}{c}\text { Eight Roads, General } \\
\text { Atlantic }\end{array}$ \\
\hline
\end{tabular}

WuXi AppTec has attracted talents at home and abroad, strengthened innovation service, and attracted investment with high-quality service and innovation mode, initially forming the path of "innovation attracts capital, capital feeds innovation". In August 2007, WuXi AppTec listed on the New York Stock Exchange, raising more than 185 million dollars, known as "Wall Street pays for China's brain for the first time".

\subsection{M \& A Expansion and Secondary Innovation Stage}

The US stock market provided WuXi AppTec a more open and broad financing platform. With the help of international capital market, WuXi AppTec acquired M \& A with advanced technology, absorbed external technology team and carried out secondary innovation in combination with the original innovation ability.

Tbble 2. The company acquired by WuXi AppTec from 2007 to 2014

\begin{tabular}{|c|c|c|}
\hline Year & Acquired company & Characteristics \\
\hline 2007 & Chemdepo & Chemical compound provider \\
\hline 2007 & Abgent & Biological reagent supplier \\
\hline 2007 & $\begin{array}{c}\text { Jiecheng, Med- } \\
\text { Key }\end{array}$ & Clinical research service company \\
\hline 2008 & AppTech & $\begin{array}{c}\text { Provider of biological services and } \\
\text { medical facilities }\end{array}$ \\
\hline 2014 & $\begin{array}{c}\text { XenoBiotic Labo- } \\
\text { ratories }\end{array}$ & $\begin{array}{c}\text { R \& D service company for bioanal- } \\
\text { ysis, drug metabolism and pharmaco- } \\
\text { kinetics }\end{array}$ \\
\hline
\end{tabular}

In this stage, the innovation of WuXi AppTec manifested as merger and acquisition. Through the support of capital market, it acquired enterprises with advanced technology and absorbed external technology to support its secondary innovation.

\subsection{Privatization and Integration Innovation Stage}

However, the development of WuXi AppTec was not smoothly. Although continuous mergers and acquisitions could make enterprises expand rapidly, Wall Street fol- 
lowed the principle of "cash as king". So they are very doubtful of the sustainability of this development model. The stock price of WuXi AppTec kept falling and its market value was undervalued. In response, Li Ge expressed with great disappointment "we want to keep innovation, but we can't get positive incentives. I think it's time to delist."

In December 2015, WuXi AppTec completed the privatization with the consideration of $\$ 3.3$ billion dollars and officially delisted. In this process, WuXi AppTec introduced several new strategic investors to support its integrated innovation.

Table 3. Financing sources of Wuxi AppTec in the initial stage

\begin{tabular}{|c|c|c|c|}
\hline Date & $\begin{array}{c}\text { Financing } \\
\text { Amount }\end{array}$ & Financing Round & Investor \\
\hline $04 / 01 / 2016$ & $¥ 10$ million & $\begin{array}{c}\text { Strategic Fi- } \\
\text { nancing }\end{array}$ & $\begin{array}{c}\text { New Alliance Capital, } \\
\text { Highlight Capital }\end{array}$ \\
\hline $11 / 09 / 2016$ & $¥ 19$ million & $\begin{array}{c}\text { Strategic Fi- } \\
\text { nancing }\end{array}$ & $\begin{array}{c}\text { Eight Roads, Tiandi Capi- } \\
\text { tal, UOB Venture Manage- } \\
\text { ment, Legend Capital }\end{array}$ \\
\hline $01 / 24 / 2017$ & Undisclosed & $\begin{array}{c}\text { Strategic Fi- } \\
\text { nancing }\end{array}$ & $\begin{array}{c}\text { Taikang, Huatai Securities, } \\
\text { China Life PE, YF Capital, } \\
\text { Huaxing Growth Capital }\end{array}$ \\
\hline
\end{tabular}

By introducing new strategic investors through privatization, WuXi AppTec successfully acquired upstream and downstream industries to expand diversified business. The investment layout included innovative biotechnology, artificial intelligence, transformative technology and medical health information technology.

\subsection{Cross-Listing and Continuous Innovation Stage}

In February 2018, the CSRC announced that it would relax the approval standards for unicorn enterprises in four new economic fields, including biotechnology, cloud computing, artificial intelligence and high-end manufacturing. Based on the previous good capital operation and innovation accumulation, WuXi AppTec successfully seized this policy dividend and listed in May 2018, raising more than 2.25 billion yuan. In December of the same year, WuXi AppTec officially listed on the Hong Kong Stock Exchange and raised about 7.5 billion Hong Kong dollars.

With "A+H" cross-listing, WuXi AppTec's capital operation capacity has been greatly enhanced. Through increasing R\&D investment, merger and acquisition, and cooperation with other innovation platforms, $\mathrm{WuXi}$ AppTec continuously improves its innovation ability and maintains its competitiveness.

\section{Summary and Conclusion}

Based on the case study of WuXi AppTec, we can expand to innovative enterprises. According to their own development stage, enterprises can reasonably use capital operation means to promote enterprise financing to support innovation, and realize the evolution of independent innovation ability through the coexistence of innovation and capital. When enterprises invest in innovation, due to the existence of financing constraints, enterprises will face the problem of insufficient innovation investment, and the financing environment and conditions faced by enterprises at different stages of development are different. Enterprises need to judge their own stage and financing environment according to their own development status. Technological innovation will indirectly provide enterprises with chips to break through financing constraints in the way of increasing enterprise value, so enterprises can obtain external equity financing in the capital market to support the innovation and development of enterprises. Under appropriate circumstances, enterprises can choose to privatize or split business, respectively listed to build financing channels of multiple capital markets, so as to alleviate financing constraints, continue innovative investment, and increase the competitiveness of enterprises.

\section{References}

[1] Brown J R, Martinsson G, Petersen B C. Do Financing Constraints Matter for R\&D? New Tests and Evidence[J]. European Economic Review, 2012:1512 1529.

[2] Czarnitzki D, Hottenrott H. Financing Constraints for Industrial Innovation: What do We Know? [J] Review of Business \& Economic Literature, 2013:346-363.

[3] Daniel Kiel, Christian Arnold, Kai-Ingo Voigt. The influence of the Industrial Internet of Things on business models of established manufacturing companies-A business level perspective [J]. Technovation, 2017: 68:4-19.

[4] David B. Audretsch, Erik E. Lehmann, Albert N. Link. Introduction to A Research Agenda for Entrepreneurship and Innovation[J]. International Entrepreneurship \& Management Journal, 2019.

[5] Muhammad Mustafa Raziq, Cristina Doritta Rodrigues, Felipe Mendes Borini. Linking Corporate Entrepreneurship, Expatriation and Reverse Knowledge Transfers[J]. European Journal of Innovation Management, 2019.

[6] Xavier Jaravel, Neviana Petkova, Alex Bell. Team-Specific Capital and Innovation[J]. Social Science Electronic Publishing, 2018:108.

[7] Yulia Gareeva, Yury Dranev, Alexander Kucherov. The Impact of Innovation Capital on Firm Values[J]. Ssrn Electronic Journal, 2018.

[8] Zhang J H, Luo S G, Luo J. Innovation Openness and Firm Performance: The Moderating Role of High Quality Human Capital [J]. Shanghai Management Science, 2019(4). 